\author{
Katarzyna BARAN-GURGUL ${ }^{1}$ \\ Marek BODZIONY ${ }^{2}$
}

\title{
SUSZA SPOŁECZNO-EKONOMICZNA A SUSZA HYDROLOGICZNA W ZLEWNI GÓRNEJ WISEY
}

\begin{abstract}
Celem artykułu jest porównanie okresów wystąpienia niedoborów w rzekach (susza hydrologiczna) z okresami niedoborów wody przeznaczonej na cele gospodarczo-komunalno-bytowe (susza społeczno-ekonomiczna), jakie zaobserwowano w gminach leżących w zlewni Górnej Wisły, w latach 1984-2014. Stwierdzono współwystępowanie tych okresów co może ułatwić określenie zagrożenia suszą oraz pozwoli na odpowiednie przygotowanie się (w szczególności w urzędach lub instytucjach zajmujących się dystrybucją wody lub klęskami żywiołowymi) na odpowiednią reakcję.

Niżówki, utożsamiane z suszą hydrologiczną wyznaczono metodą SPA przyjmując przepływ graniczny równy $Q_{70 \%}$, a minimalny czas trwania - 7 dni.

Okresy z niedoborem wody określono bazując na ankietach rozesłanych do władz powiatowych i gminnych oraz innych instytucji związanych $\mathrm{z}$ zaopatrzeniem w wodę.
\end{abstract}

Słowa kluczowe: niżówka, niedobór wody, czas trwania niżówki, ankietyzacja, susza hydrologiczna, susza społeczno-ekonomiczna

\section{Wstęp}

W Europie Środkowej susze pojawiają się okresowo i trwają od kilku tygodni do kilku miesięcy. Znaczące susze w Europie zaobserwowano m. in. w latach 1962-64, 1975-76, 1995-97 [13]. Lorenc i in. [2006], którzy opracowali „Katalog występowania susz w Polsce w okresie 1951-2011” zauważyli, że częstość występowania susz zwiększyła się. W okresie 1951-81 suszę obserwowano co 5 lat, w latach późniejszych (1982-2011) susza występowała średnio co 2 lata. Susze katastrofalne w tym okresie wystąpiły w latach: 1982, 1992, 1994, 2006 i 2011.

\footnotetext{
${ }^{1}$ Autor do korespondencji/corresponding author: Katarzyna Baran-Gurgul, Politechnika Krakowska, 31-155 Kraków, ul. Warszawska 24, tel. 12628 2189, Katarzyna.Baran-Gurgul@iigw.pk.edu.pl

${ }^{2}$ Marek Bodziony, Politechnika Krakowska, 31-155 Kraków, ul. Warszawska 24, tel. 126282855 , Marek.Bodziony@iigw.pk.edu.pl
} 
Susza jest procesem złożonym, narasta stopniowo, a jej skutki kumulują się i uwidaczniają po dłuższym czasie. Jak zauważa Łabędzki [2004] nie ma możliwości wpływania na pojawienie się suszy. Wrażliwość na suszę jest zdeterminowana wieloma czynnikami (społecznymi, gospodarczymi, technologicznymi, politycznymi), którymi można regulować. Susze zatem mogą mieć różne skutki, nawet jeśli czas ich trwania, natężenie i zasięg przestrzenny są identyczne. Dlatego nie można podać jednej, uniwersalnej definicji suszy, ponieważ zależy ona od specyfiki danego obszaru.

Beran i Rodier [1985], a za nimi Hisdal i Tallaksen [2000] definiują suszę jako długotrwały spadek dostępności wody w określonym czasie na danym obszarze. Tallaksen i van Lanen [2007] określają suszę jako trwałe i rozległe obszarowo obniżenie poniżej średniej naturalnej dostępności wody, co może mieć wpływ na wszystkie elementy obiegu wody. International Glossary of Hydrogeology, a także Magnuszewski, Soczyńska [2001] określają suszę jako długotrwały brak lub znaczący niedostatek opadów.

W polskim prawodawstwie definicję suszy, a ściślej trzech faz jej rozwoju, można znaleźć w Rozporzadzeniu Ministra Środowiska z 22 sierpnia 2007 roku, według którego:

- stan suszy atmosferycznej to wystąpienie długotrwałego niedoboru lub braku opadów w okresie wegetacyjnym,

- stan suszy glebowej to wystąpienie wysychania powierzchni gleby i jej głębszych warstw spowodowane suszą atmosferyczną;

- stan suszy hydrologicznej to zmniejszenie odpływu wód gruntowych do wód powierzchniowych i w efekcie zmniejszenie przepływu w rzekach co najmniej trzech zlewni monitorowanych przez podstawową sieć obserwacyjno-pomiarową państwowej służby hydrologiczno - meteorologicznej poniżej odpowiadającego SNQ.

Wilhite i Glanz [1987] przeanalizowali ponad 150 opublikowanych definicji suszy i wyróżnili 4 fazy jej rozwoju:

- susza meteorologiczna charakteryzuje sytuację, w której opad jest znacznie niższy od normalnego na danym obszarze. Klimatolodzy za stan „,normalny” uważają średni z 30 lat [National Drought Mitigation Center 2013]. Susza meteorologiczna odzwierciedla jedną z podstawowych przyczyn suszy.

- susza rolnicza to okres, w którym wilgotność gleby jest niedostateczna do zaspokojenia potrzeb wodnych roślin i ich uprawy. Susze te charakteryzują się brakiem wilgoci w strefie korzeniowej roślin i nie zależą wyłącznie od ilości opadów. Ta sama ilość opadów w styczniu i lipcu będzie miała różne skutki. Susze występujące w zimie mogą mieć niewielki wpływ na uprawy. Jednakże w lecie, kiedy temperatury są wyższe a dni dłuższe, rośliny zużyją więcej wody $\mathrm{w}$ strefie korzeniowej. W związku z tym, susze letnie są bardziej widoczne i powodują więcej szkód. Umiarkowana susza w okresie wzrostu roślin może spowodować zahamowanie wzrostu roślin i obniżenie 
plonów. Susza w tym samym czasie może jednak prowadzić do całkowitego uszkodzenia upraw.

- susza hydrologiczna określa braki w powierzchniowych i podziemnych zasobach wody pitnej. Obserwuje się spadek przepływu wody w rzekach (niżówki) oraz wysychanie źródeł i małych cieków.

- susza społeczno-ekonomiczna obejmuje definicje łączące podaż i popyt na dobra gospodarcze (np. wodę, ziarno, hydro-energię elektryczną) $\mathrm{z}$ elementami meteorologii, hydrologii lub suszami rolniczymi.

Rozwijanie się suszy w czasie i na obszarze przebiega różnie w zależności od wielu parametrów klimatu i środowiska. Zawsze jednak można zaobserwować poszczególne fazy jej rozwoju. Początkową fazą suszy jest susza atmosferyczna inicjowana przez niedobór lub brak opadów. Jeśli okres niedoborów opadów zbiegnie się z upałami i zwiększonymi prędkościami wiatru czy usłonecznieniem, wówczas wzrasta intensywność parowania, zauważa się przesychanie powierzchniowych, a następnie głębszych warstw gleby. Redukowane są zasoby wody wolnej, wsiąkowej i w końcu kapilarnej (obserwuje się suszę glebową). Gdy zasoby wód podziemnych nie są uzupełniane wodami opadowymi, następuje obniżanie się zwierciadła wód podziemnych i obniżenie stanów wód powierzchniowych [21]. Ta faza suszy nazywana jest suszą hydrologiczną. W końcu obserwuje się deficyt wody do celów gospodarczo-komunalnobytowych (susza społeczno-ekonomiczna).

Jaka jest zależność pomiędzy suszą hydrologiczną a społecznoekonomiczną? Aby odpowiedzieć na to pytanie wyznaczono okresy niedoboru wody w rzekach (okresy niżówkowe) oraz określono okresy z niedoborem wody na cele gospodarczo-komunalno-bytowe w obszarach przyległych (gminach). Obszarem badań jest karpacka część zlewni Górnej Wisły.

Niżówki utożsamiane z suszą hydrologiczną wyznaczono metodą SPA, przyjmując przepływ graniczny równy $Q_{70 \%}$, a minimalny czas trwania niżówek - 7 dni. Na podstawie informacji zawartych w ankietach rozesłanych do władz powiatowych i gminnych oraz innych instytucji związanych z zaopatrzeniem w wodę określono okresy, w których zaobserwowano niedobory wody w poszczególnych gminach.

Bazując na danych $\mathrm{z}$ ankiet oraz obliczeniach dotyczących niżówek stwierdzono, że pomiędzy tymi parametrami istnieje koincydencja, która może ułatwić określenie zagrożenia suszą oraz pozwoli na odpowiednie przygotowania się (w szczególności w urzędach lub instytucjach zajmujących się dystrybucją wody lub klęskami żywiołowymi) na odpowiednią reakcję.

\section{Ankiety}

Ankietyzacją został objęty obszar dorzecza Górnej Wisły. Zakres pytań dotyczył konieczności dostarczania wody w okresach niedoborów (i nie tylko) na cele bytowe, komunalne i rolnicze. Ankiety zostały wysłane do urzędów gmin, 
urzędów miejskich i powiatowych, niektórych przedsiębiorstw wodociągowych, jednostek straży pożarnej i innych miejsc związanych z dystrybucją wody na obszarach gmin. Ze względu na posiadane dane hydro i meteorologiczne $\mathrm{z}$ lat 1984-2014, do urzędów wysłano ankiety z prośbą o określenie miejsc (miejscowość, wieś, ulica), w których była dystrybuowana woda właśnie w tym okresie. Wysłano 598 zapytań do gmin leżących w pięciu województwach w dorzeczu Górnej Wisły (tabela 1).

Tabela 1. Liczebność ankiet jakie zostały wysłane do gmin w poszczególnych województwach Table 1 . The number of the questionnaires sent to the communes in the particular provinces

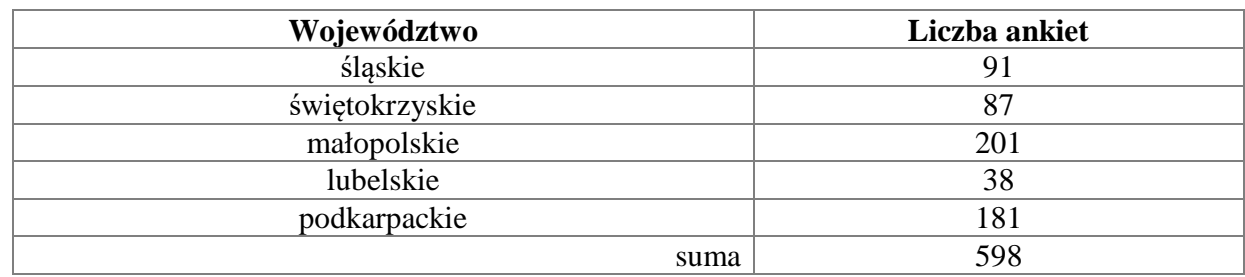

Zasięg zapytań ankietowych obejmował 533 gminy. Odpowiedź uzyskano tylko z 193 gmin, co stanowi zaledwie 36\% ankietowanych. Spośród 193 gmin dane dotyczące zaopatrzenia $\mathrm{w}$ wodę $\mathrm{w}$ okresach jej niedoboru posiadało 168 gmin (32\% ankietowanych). Rozkład przestrzenny tych gmin przedstawiono na rys. 1.

W okresie ankietyzacji, czyli w latach 1984-2014, w 70 gminach przynajmniej raz wystąpiła konieczność dowozu wody (rys. 2). Są ty gminy leżące w zlewni Dunajca lub jej okolicach. W pozostałych gminach nie odnotowano konieczności dowozu wody lub gminy nie posiadały danych.

Zestaw danych dotyczących niedoborów wody w gminach jest niekompletny, gdyż znaczna część gmin albo nie odpowiedziała na ankiety, albo przysłała informację, że nie posiada danych nas interesujących. Brak odpowiedzi może świadczyć o niezbyt rzetelnym podejściu gmin do współpracy z instytucjami takimi jak wyższe uczelnie. Zauważyć należy przede wszystkim, jak ubogie zasoby danych znajdują się w archiwach gmin. Niedostateczna ilość materiałów w znacznym stopniu ogranicza zakres czasowy i przestrzenny badań, ale może stanowić wstęp do bardziej rozbudowanych analiz.

Analiza nadesłanych ankiet wskazała na konieczność zawężenia okresu badań, gdyż gminy nie dostarczyły informacji dotyczących lat najwcześniejszych. Liczba danych jest znacząca dopiero po 2005 roku. 


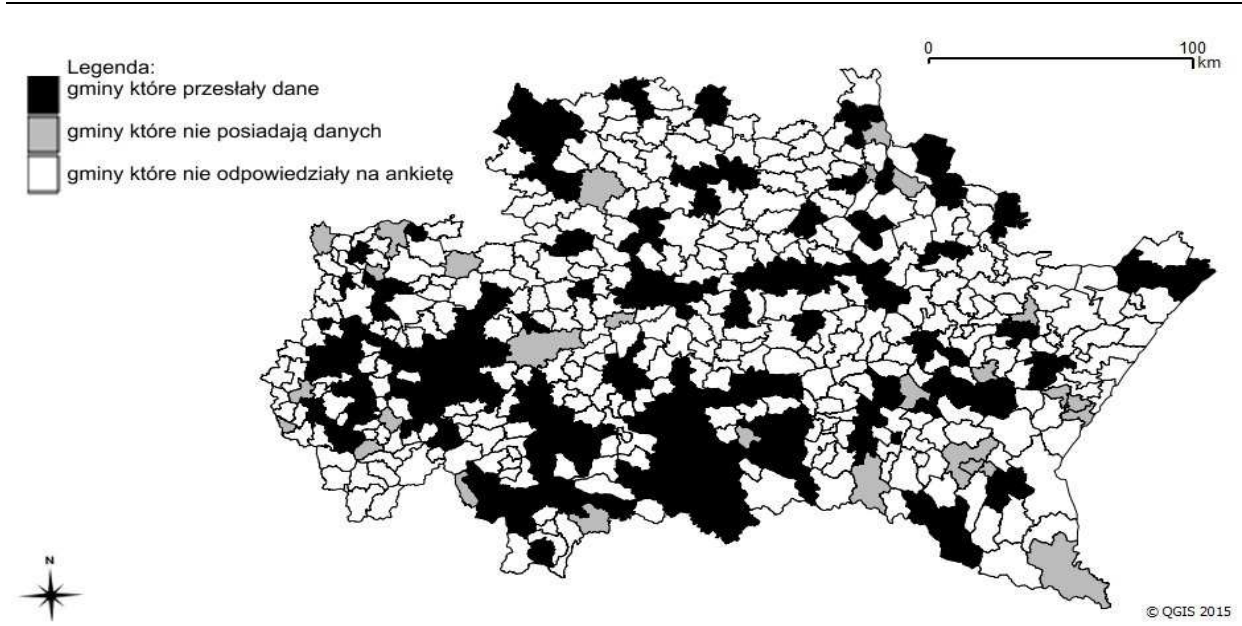

Rys. 1. Lokalizacja gmin z obszaru dorzecza Górnej Wisły, które przesłały ankiety

Fig. 1. The location of the communes from the area of the upper Vistula river basin, which sent the questionnaires

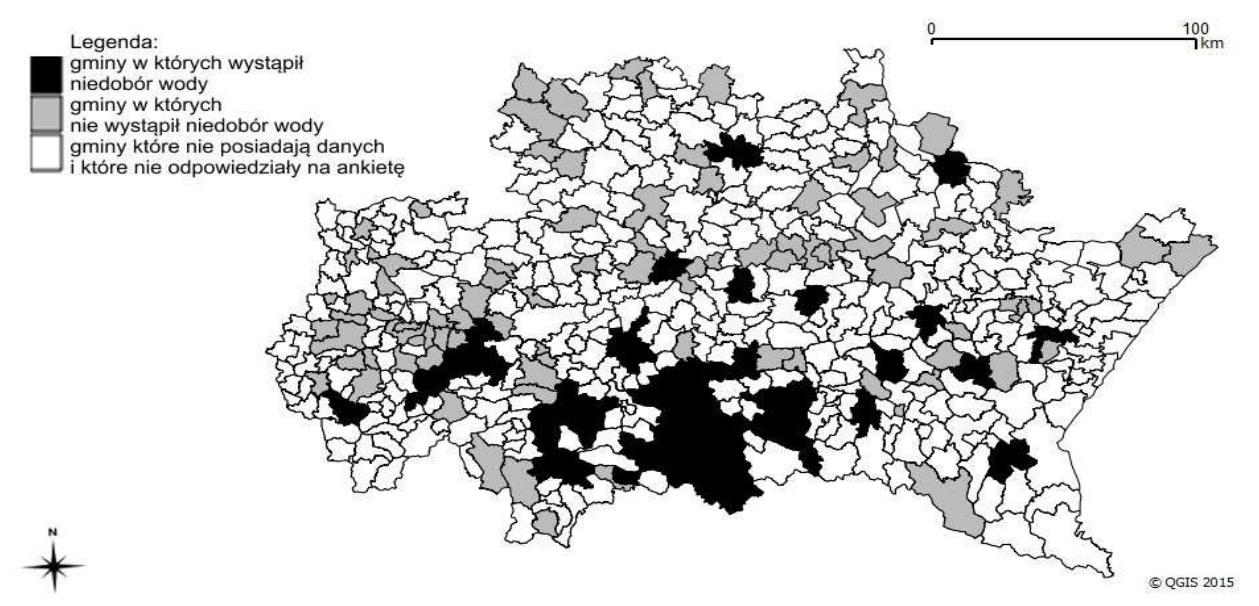

Rys. 2. Lokalizacja gmin, w których wystąpił niedobór wody na cele bytowo-komunalno-rolnicze w latach 1984-2014

Fig. 2. The location of the communes in which there was the deficit of water for the living and communal-agricultural purposes between 1984 and 2014

Na rys. 3 zestawiono liczbę gmin (z podziałem na lata), w których zaobserwowano niedobory, w których nie było problemów z niedoborem wody oraz liczbę gmin, od których nie udało się uzyskać danych. Mała liczba zaobserwowanych okresów suszy w latach wcześniejszych może wynikać z braku takiej informacji w gminach lub że problem ten nie występowat. Potwierdza to informacja przedstawiona na rys. 4 - liczebność gmin, które w ankiecie zasygnalizowały problem suszy jest największa w ostatnich latach. 
Dowożona woda w okresach suchych przeznaczona była zazwyczaj na cele bytowe (w $68 \%$ przypadków) i komunalne (w 20\%) - rys. 5.

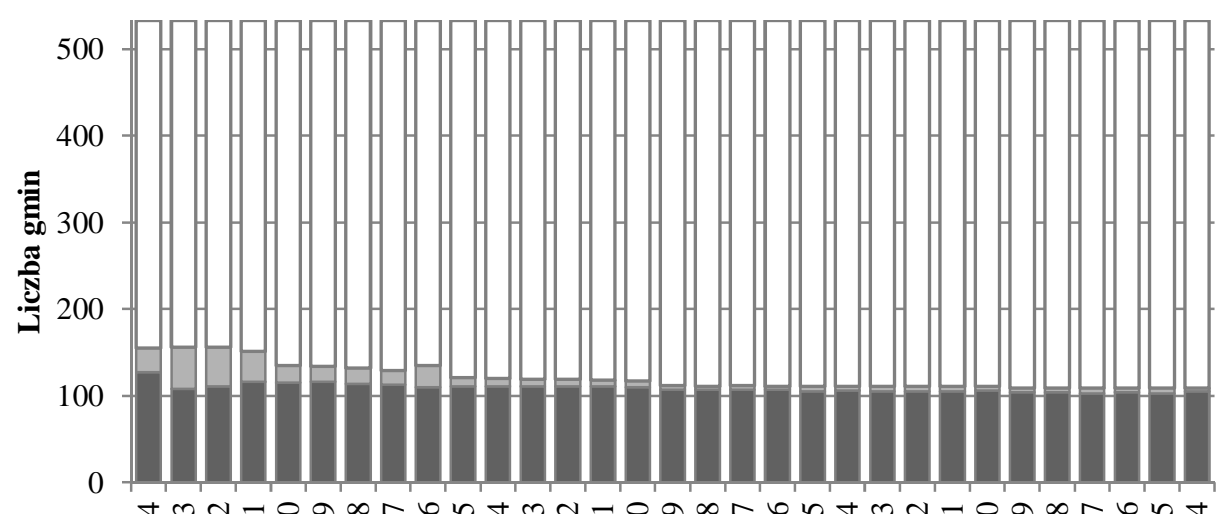

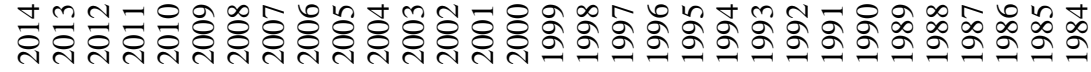

$\square$ gminy nie posiadające danych i gminy, które nie udzieliły odpowiedzi na ankietę

$\square$ gminy do których dowożono wodę

aminy w których nie stwierdzono problemów z wodą

Rys. 3. Zestawienie liczby gmin poddanych ankietyzacji

Fig. 3. The comparison of the number of communes to which the questionnaires were sent

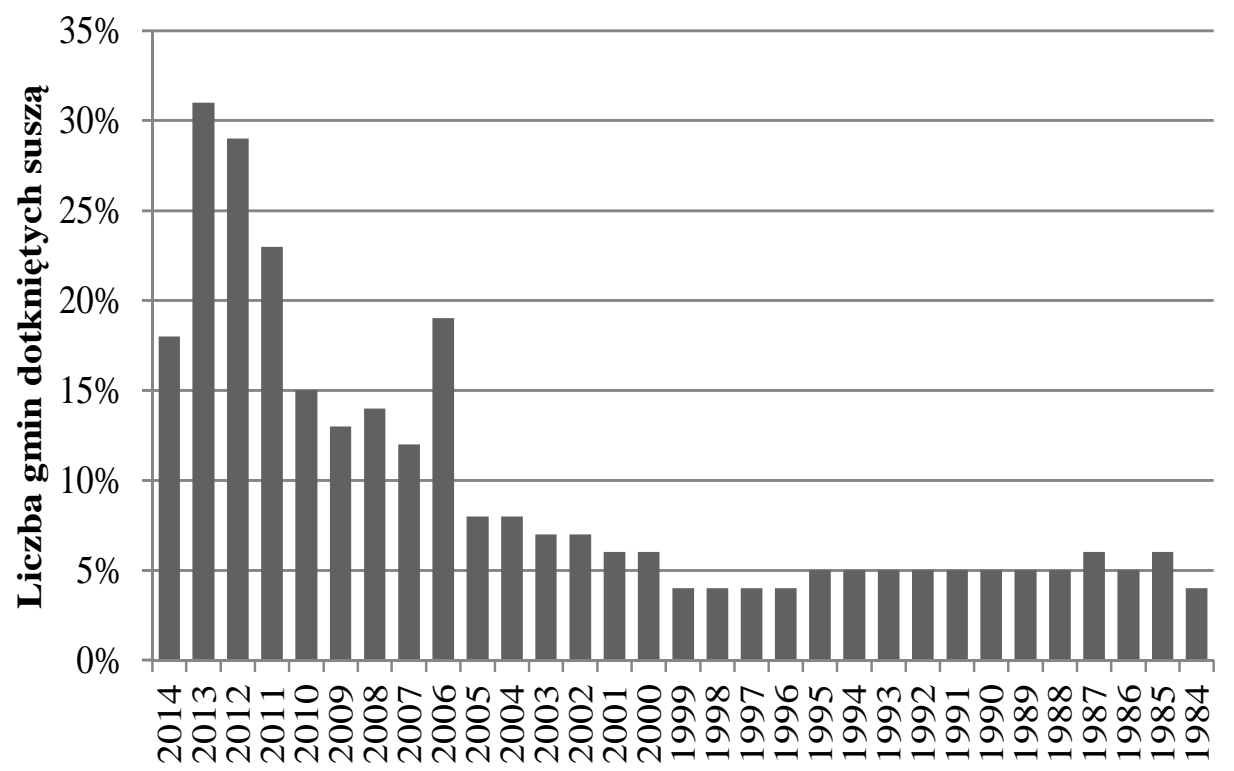

Rys. 4. Liczba gmin dotkniętych suszą w poszczególnych latach

Fig. 4. The number of communes affected by drought in the following years 


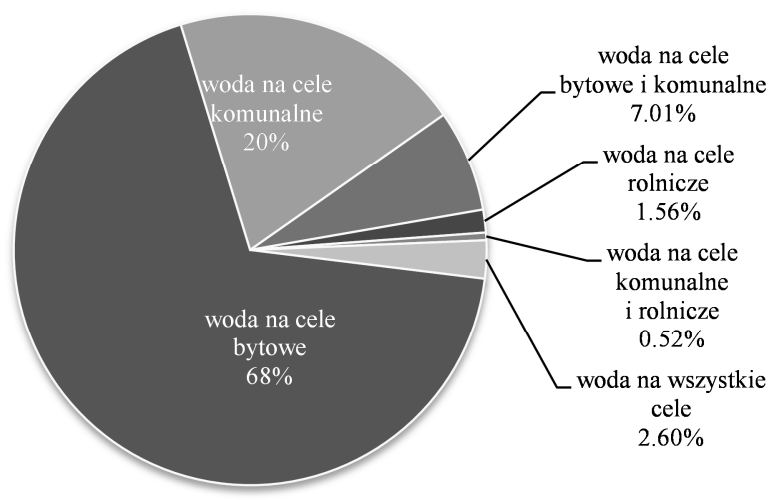

Rys. 5. Cele, na które została wykorzystana woda dostarczana podczas jej niedoborów w latach 1984-2014 (zestawienie procentowe)

Fig. 5. The aims, for which the water provided during the deficit in 1984-2014 was used (the percentage)

\section{Niżówki}

Niżówka rzeczna najczęściej definiowana jest jako proces nieprzerwanego utrzymywania się przepływu (lub stanu) wody w danym przekroju cieku poniżej umownie przyjętej wartości granicznej [12, 19, 24, 17, 14]. V.U. Smakhtin [2001] uważa za niżówkę okres przepływów w rzece utrzymujących się w suchych warunkach pogodowych. H. Hisdal i L. M. Tallaksen [2000] utożsamiają niżówkę z suszą hydrologiczną, natomiast Ratomska [1993] czy Tokarczyk [2013] postrzegają ją jako wskaźnik tej suszy. W okresie zimowym zjawisko to może być spowodowane przemarzaniem gruntu i ograniczeniem lub odcięciem drenażu wód podziemnych [21]. Zasięg przestrzenny niżówek, w przeciwieństwie do wezbrań, nie ogranicza się do jednej lub kilku rzek. Zwykle obejmuje większe obszary (dorzecza lub regiony). Na podstawie historycznych danych dobowych wyznaczono niżówki w 90 przekrojach wodowskazowych, których lokalizację przedstawiono na rys. 6 . Niźówka jest okresem, w którym przepływy są niewiększe od przyjętego przepływu granicznego $Q_{g}$. Przepływ ten, zwany także wartością progową [5] lub poziomem odcięcia [21, 15], najczęściej przyjmowany jest jako stała wartość w ciągu roku będąca kwantylem $Q_{p}$ rzędu $p$ odczytanym $\mathrm{z}$ wieloletnich krzywych sum czasów trwania przepływów dobowych. Wartości prawdopodobieństwa przekroczenia przepływu $p$, przyjmowane są w zależności od autora jako: 70, 80, 90 lub 95\% [26, 5, 17, 23, 18]. W niniejszej pracy za przepływy graniczne przyjęto przepływy $Q_{70 \%}$, określone ze wspomnianych krzywych. W celu eliminacji krótkich, nieistotnych jako okres braku wody, epizodów przepływów $Q>Q_{g}$ przyjęto dodatkowo minimalny czas $t_{\min }$ trwania niżówki. W literaturze przedmiotu przyjmowane są różne wartości tego czasu, od 5 do 14 dni $[7,21,19,6]$. W niniejszej pracy przyjęto $t_{\min }=7 \mathrm{dni}$. 


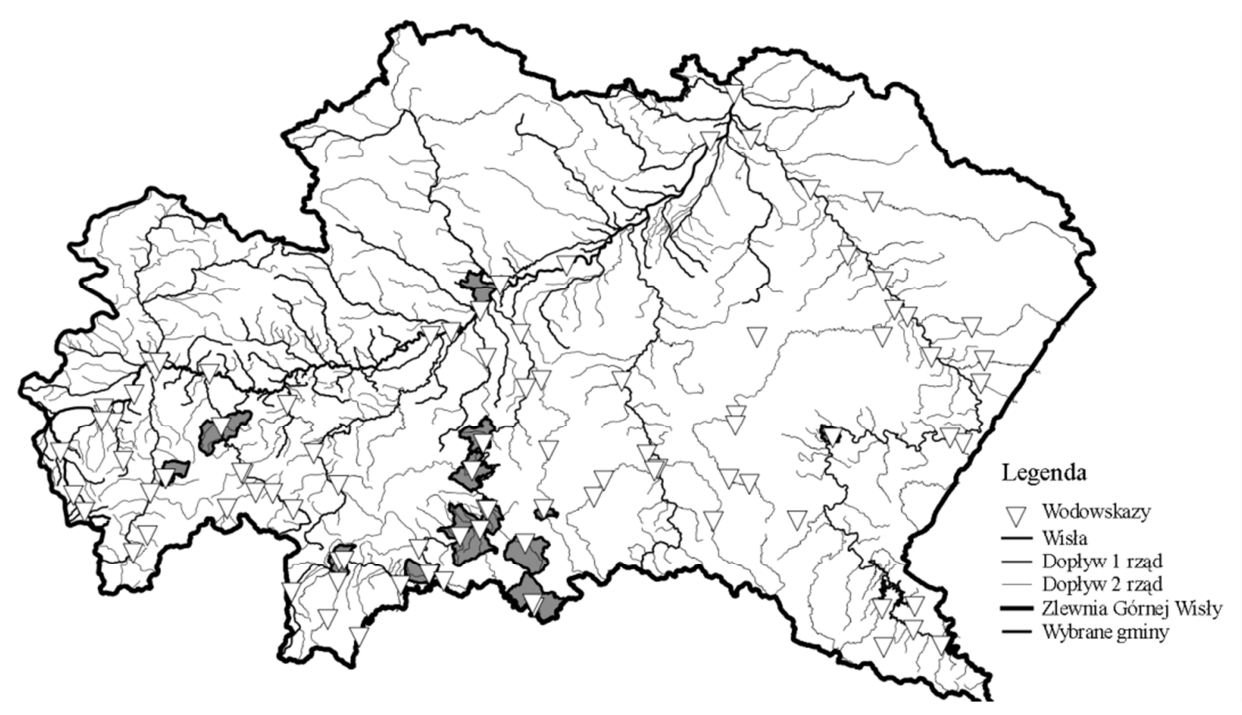

Rys. 6. Lokalizacja przekrojów wodowskazowych

Fig. 6 . The location of the water gauge cross-section

W niniejszej pracy niżówka jest definiowana metodą SPA (Sequent Peak Algorytm). Wyznaczanie niżówki zależy od przyjętego natężenia przepływu granicznego $Q_{g}$, a początek niżówki następuje w chwili obniżenia się przepływu poniżej $Q_{g}$. Metoda SPA opiera się na krzywej sumowej odpływu i powstała w celu szacowania objętości zbiornika retencyjnego. Obecnie stosowana forma algorytmu została wprowadzona przez R. M. Vogela i J. R. Stedingera [1987]. Tę metodę obliczeń stosowało wielu autorów, m.in. T. Tallaksen i H. A. J. van Lanen [2004], A. K. Fleig [2004] i W. Jakubowski [2011]. W tej metodzie obliczeń koniec niżówki następuje zgodnie z jej definicją w momencie wyrównania powstałego niedoboru wody przepływem wyższym od $Q_{g}$, a zatem gdy obliczana dla kolejnych wartości $t$ różnica $Q_{g}-Q_{t}$ przestanie być dodatnia. Doba, w której deficyt osiąga wartość maksymalną określa m.in. czas $t_{n}$ trwania niżówki.

Aby porównać suszę hydrologiczną z danymi pochodzącymi z ankiet, w każdym przekroju wodowskazowym wyznaczono liczebność dni niżówkowych w danym miesiącu, danego roku.

\section{Wyniki badań i analiza}

Zestawienie danych z ankiet otrzymanych od gmin wskazało, że gminy dostarczyły dane właściwie tylko z lat 2005-2014, a dowóz wody konieczny był głównie na terenie zlewni Dunajca i jej okolic.

Do porównania suszy społeczno-ekonomicznej i hydrologicznej wykorzystano niżówki obliczone na podstawie historycznych ciągów przepływów w 90 
przekrojach wodowskazowych na rzekach w zlewni Górnej Wisły. Ponieważ dane z wodowskazów pochodzą z okresu od 1.11.1983 r. do 30.10.2013 r., więc w artykule ograniczono się do okresu od 1.01.2005 r. do 30.10.2013 r., czyli 106 miesięcy.

Tabela 2 zawiera podstawowe dane dotyczące posterunków wodowskazowych znajdujących się gminach, w których przynajmniej raz został zgłoszony problem z wodą (m.in. wartości przepływów granicznych $Q_{g}=Q_{70 \%}$ odczytane z krzywych sum czasów trwania przepływów dobowych).

$\mathrm{Z}$ analiz danych pochodzących $\mathrm{z}$ ankiet otrzymanych $\mathrm{z}$ gmin wynika że

- w 100 gminach nie wystąpił problem z niedoborem wody w badanym okresie,

Tabela 2. Podstawowe informacje o wybranych posterunkach wodowskazowych

Table 2. The basic information of selected water gauge cross-section

\begin{tabular}{|c|c|c|c|c|c|c|c|}
\hline Lp. & Wodowskaz & Rzeka & $\boldsymbol{H}$ & $x$ & $y$ & $Q_{70 \%}$ & GMINA \\
\hline 1 & Koniówka & Dunajec & 725,3 & 49,3956 & 19,8181 & 1,85 & Czarny Dunajec \\
\hline 2 & Nowy Targ & Dunajec & 579,3 & 49,4869 & 20,0536 & 3,75 & Nowy Targ \\
\hline 3 & $\begin{array}{l}\text { Nowy Targ- } \\
\text { Kowaniec }\end{array}$ & Dunajec & 547,3 & 49,4844 & 20,0311 & 6,60 & Nowy Targ \\
\hline 4 & Krościenko & Dunajec & 413,4 & 49,4417 & 20,4294 & 15,00 & Krościenko \\
\hline 5 & Gołkowice & Dunajec & 312,9 & 49,5503 & 20,5703 & 17,70 & Podegrodzie \\
\hline 6 & Nowy Sącz & Dunajec & 275,7 & 49,6272 & 20,6872 & 30,60 & Nowy Sącz \\
\hline 7 & Czchów & Dunajec & 275,7 & 49,8164 & 20,6819 & 29,60 & Czchów \\
\hline 8 & Zgłobice & Dunajec & 190,7 & 49,9750 & 20,8797 & 32,81 & Wierzchosławice \\
\hline 9 & Żabno & Dunajec & 173,4 & 50,1319 & 20,8619 & 37,70 & Żabno \\
\hline 10 & $\begin{array}{l}\text { Zakopane- } \\
\text { Harenda }\end{array}$ & Cicha Woda & 763,1 & 49,3161 & 19,9772 & 1,07 & Zakopane \\
\hline 11 & Szaflary & Biały Dunajec & 636,4 & 49,4242 & 20,0247 & 2,54 & \begin{tabular}{|l|} 
Szaflary \\
\end{tabular} \\
\hline 12 & Łysa Polana & Białka & 965,8 & 49,2636 & 20,1150 & 1,02 & Bukowina Tatrz. \\
\hline 13 & Niedzica & Niedziczanka & 495,5 & 49,4114 & 20,3022 & 0,68 & Łapsze Niżne \\
\hline 14 & Szczawnica & Grajcarek & 452,9 & 49,4203 & 20,4933 & 0,51 & Szczawnica \\
\hline 15 & Tylmanowa & Ochotnica & 394,3 & 49,5172 & 20,3869 & 0,73 & Ochotnica Dolna \\
\hline 16 & Muszyna & Poprad & 446,3 & 49,3394 & 20,8919 & 8,00 & \begin{tabular}{|l|} 
Muszyna \\
\end{tabular} \\
\hline 17 & Muszyna-Milik & Poprad & 440,4 & 49,3500 & 20,8853 & 9,00 & Muszyna \\
\hline 18 & Stary Sącz & Poprad & 297,3 & 49,5686 & 20,6597 & 11,10 & Stary Sącz \\
\hline 19 & Łabowa & Kamienica & 446,2 & 49,5264 & 20,8589 & 0,34 & Łabowa \\
\hline 20 & Nowy Sącz & Kamienica & 279,0 & 49,6253 & 20,6958 & 1,10 & Nowy Sącz \\
\hline 21 & Jakubkowice & Łososina & 248,3 & 49,7394 & 20,6300 & 1,39 & Łososina Dolna \\
\hline 22 & Grybów & Biała & 319,7 & 49,6239 & 20,9458 & 0,62 & Grybów \\
\hline 23 & Ciężkowice & Biała & 238,6 & 49,7922 & 20,9736 & 1,57 & Ciężkowice \\
\hline 24 & Koszyce Wielkie & Biała & 190,7 & 49,9972 & 20,9494 & 3,15 & Tarnów \\
\hline 25 & Dynów & San & 234,8 & 49,8008 & 22,2442 & 19,60 & Dynów \\
\hline 26 & Jagodniki & Wisła & 170,0 & 50,2006 & 20,6819 & 66,00 & Opatowiec \\
\hline 27 & Karsy & Wisła & 166,7 & 50,2750 & 20,7747 & 104,00 & Opatowiec \\
\hline 28 & Łękawica & Kocierzanka & 386,7 & 49,7281 & 19,2617 & 0,20 & Łękawica \\
\hline 29 & Wadowice & Skawa & 255,2 & 49,8772 & 19,5111 & 4,17 & Wadowice \\
\hline
\end{tabular}

$H$ - położenie zera wodowskazu [m n.p.m.], $x, y$-szerokość i długość geograficzna,

$Q_{70 \%}$ odczytane z krzywych sum czasów trwania przepływów dobowych $\left[\mathrm{m}^{3} / \mathrm{s}\right]$ 
- jak widać na rys. 7, w co najmniej dwóch gminach (Czchów i Nowy Sącz) problem z niedoborem wody jest procesem ciągłym,

- w 4 gminach niedobór wody występuje sporadycznie.

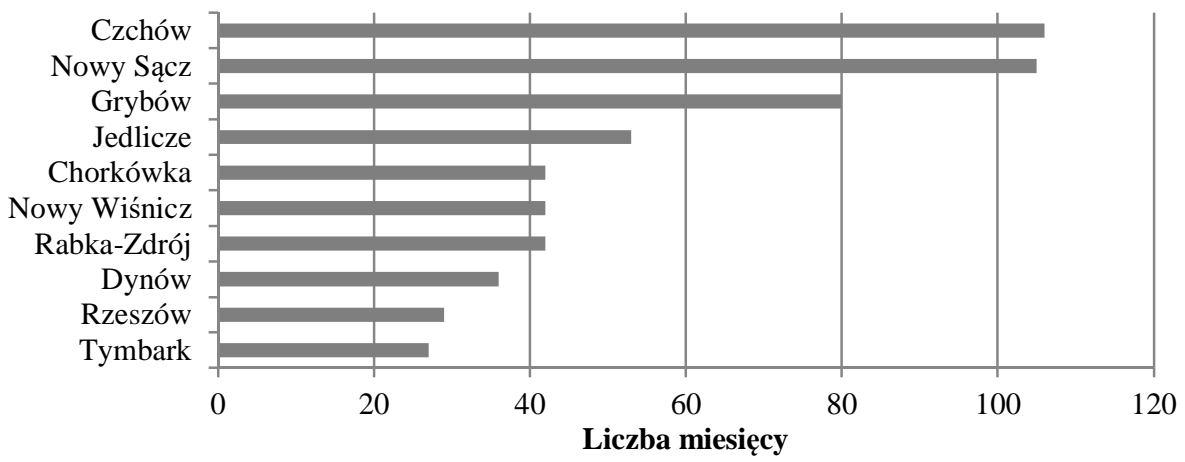

Rys. 7. Gminy do których przez najwięcej miesięcy dowożono wodę

Fig. 7. The commune which the most months supplied water

Aby porównać dane dotyczące niżówek obliczonych we wspomnianych wcześniej 29 przekrojach wodowskazowych i wystąpienia niedoborów wody na obszarach gmin, informacje zestawiono w 4 kategorie (wyniki przedstawiono na rys. 8):

- Kategoria 1. Gminy z dobrze rozwiązanym systemem zaopatrzenia w wodę (mimo występowania niżówek nie ma problemów z niedoborem wody).

- Kategoria 2. Gminy z niewłaściwie rozwiązanym systemem zaopatrzenia w wodę (pomimo braku niżówek występują problemy z niedoborem wody).

- Kategoria 3. Gminy (prawdopodobnie) bez sieci wodociągów (występowanie niżówek jest powiązane z niedoborem wody).

- Kategoria 4 Brak danych (około 60\% gmin).

Najbardziej interesującą kategorią jest kategoria 3, która łączy niżówki $\mathrm{z}$ niedoborami wody $\mathrm{w}$ gminach (dane $\mathrm{z}$ ankiet). Dlatego to właśnie tę kategorię przyjęto do dalszych analiz. W tabeli 3 pokazano wyniki obliczeń niżówek $\mathrm{i}$ dane $\mathrm{z}$ ankiet na 8 przykładach. I tak w pierwszej z tabel przedstawiono wyniki z lat 2011-2013 dla wodowskazu Muszyna Milik leżącego w gminie Muszyna na rzece Poprad. Susza hydrologiczna trwała od września 2011 r. do lutego 2012 r. W tym okresie gmina dostarczała wodę dla mieszkańców w listopadzie i w lutym.

Każdy z wybranych zestawów danych dotyczy obszaru o nieco odmiennych właściwościach hydrologicznych, jak i fizjograficznych, a także pokrycia terenu i sposobu jego zagospodarowania. To powoduje, że relacje pomiędzy występowaniem niżówek w ciekach a niedoborem wody występującym na ob- 


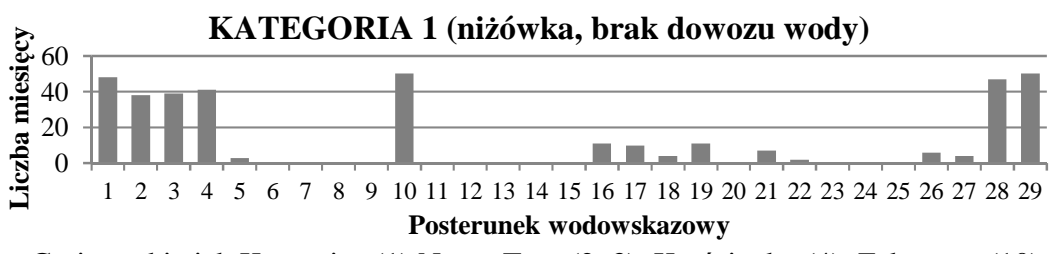

Gminy takie jak Kowaniec (1) Nowy Targ (2, 3), Krościenko (4), Zakopane (10), Łękawica (28) czy Wadowice (29) mają sprawnie działające wodociągi i mimo, że w rzece obserwuje się niżówkę, nie ma potrzeby dowozu wody.

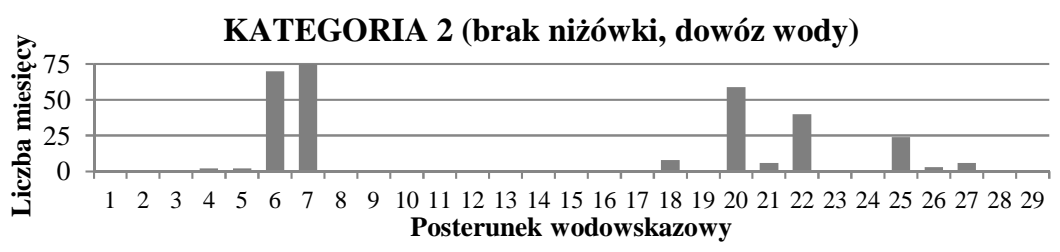

W kilku przypadkach, mimo że nie zaobserwowano niżówki rzecznej gminy zanotowały dowóz wody (dotyczy to m.in. gmin Czchów (7)

i Nowy Sącz (22), które zgłaszają ciągły problem z wodą (rys. 7)).

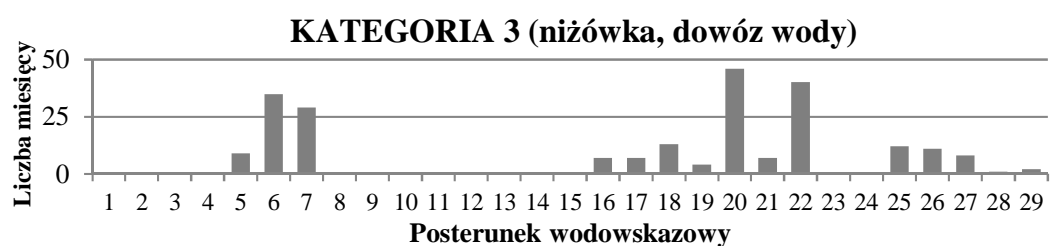

Największa zgodność suszy hydrologicznej i społeczno-ekonomicznej obserwowana jest przekrojach 6, 7, 20 i 21, ale Czchów (7) i Nowy Sącz (22) mają stały problem z wodą.

Rys. 8. Zgodność suszy społeczno-ekonomicznej z hydrologiczną według przyjętych kategorii

Rys. 8. Compatibility of socio-economic drought and hydrological drought according to the adopted category

szarach gmin jest zróżnicowane. Niemniej taka zależność istnieje i można określić pewne jej własności:

- niedobór wody na obszarach gmin ma miejsce wówczas, gdy w danym miesiącu lub miesiącu go poprzedzającym w ciekach obserwuje się niżówki, a ich liczba jest dni jest większa niż 20;

- czas trwania niedoboru wody na obszarach gmin jest również związany $\mathrm{z}$ występowaniem niżówek w ciekach i trwa on z reguły od 1 do 4 miesięcy dłużej niż niżówka;

- $\mathrm{w}$ miesiącach zimowych relacje pomiędzy niżówkami a niedoborem wody mogą mieć nieco odmienny przebieg - zależy to od ilości śniegu i wysokości temperatur (zależność ta nie została jednak sprawdzona).

Niestety przy obecnie posiadanej ilości danych uogólnienie tych zależności jest niemożliwie - zarówno pod kątem rozkładów czasowych, jak i przestrzennych. Aby takie zależności można było określić należy uzupełnić bazę danych. 
Niemniej jednak można wywnioskować, że istnieje koincydencja między liczbą dni, w których występują niżówki w ciekach a okresami z niedoborem wody. Relacje te można wykorzystać nie tylko do określania okresów suszy, ale również jako pomoc dla władz gminnych lub innych instytucji zarządzającymi sytuacjami kryzysowymi.

\section{Podsumowanie i wnioski}

Wykorzystując obliczenia dotyczące niżówek w ciekach można określić okres suszy w danej gminie i prognozować występowanie niedoborów wody występujących na jej obszarze. Wymaga to jednak posiadania dostatecznie dużej ilości danych, których zdobycie nie jest proste. Brak danych (zwłaszcza archiwalnych, sprzed 2005 roku) świadczy o niezbyt dużym zainteresowaniu władz gmin problemami suszy. Tak znikoma ilość uzyskanych odpowiedzi na ankiety ogranicza czasowy i przestrzenny zakres analiz.

Na obszarach gmin w których system zaopatrzenia w wodę działa poprawnie, susza hydrologiczna nie stanowi problemu związanego z niedoborem wody dla celów bytowo-komunalno-gospodarczych, zatem określenie relacji pomiędzy niedoborem wody a okresami niżówek nie jest konieczne.

Gdy jednak w gminie system dystrybucji wody jest niewystarczający, nawet $\mathrm{w}$ okresach bezniżówkowych istnieje konieczność dostarczania dodatkowych ilości wody. Dla takich obszarów określenie relacji pomiędzy niżówkami a okresami z niedoborem wody jest bardzo utrudnione lub wręcz niemożliwe.

W rozpatrywanych przez nas gminach, zauważyć można zależność między niżówkami występującymi w ciekach a okresami z niedoborem wody na obszarach gmin. W zależności od właściwości hydro-fizjograficznych i antropogenicznych obszaru konieczność dodatkowego dostarczania wody w gminach rozpoczyna się w tym samym miesiącu lub w miesiącu następnym od momentu pojawienia się niżówek (zazwyczaj po kilkudziesięciu dniach). Dostarczanie wody na obszarze gminy jest koniecznie w okresie od 1 do kilku miesięcy po zakończeniu okresu występowania niżówek w ciekach.

Określenie dokładnych relacji (czasowych i przestrzennych) pomiędzy niżówkami występującymi w ciekach a okresami niedoboru wody na obszarach gmin wymaga uzupełnienia i uszczegółowienia informacji dotyczących niedoboru wody w gminach. Relacje te mogą być wykorzystane zarówno do określenia okresów suszy, jak i mogą stanowić informacje pomocnicze w sztabach zarządzających sytuacjami kryzysowymi.

Niniejsze opracowanie może stanowić wstęp do określenia zależności pomiędzy liczbą dni z suszą hydrologiczną a okresami niedoboru wody na obszarach gmin na różnych płaszczyznach zarówno czasowych (rozkład relacji w czasie) jak i przestrzennych (zarówno w tych gminach, w których znajduje się wodowskaz, jak również $\mathrm{w}$ gminach sąsiednich, położonych powyżej i poniżej wodowskazu). 
Praca została wykonana w ramach tematu Ś-1/378/2013/DS Wpływ czynników antropogennych na ilościowe $i$ jakościowe wtaściwości procesów hydrologicznych w zlewni, zadanie 3: Analiza własności nizówek w obszarze karpackim zlewni Górnej Wisty, na podstawie danych z posterunków wodowskazowych IMGW - PIB.

\section{Załącznik. Tabelaryczne zestawienie dni z niżówką}

Tabela 3. Porównanie liczby dni z niżówką w danym miesiącu, w określonym przekroju wodowskazowym, z informacjami dotyczącymi braku wody pozyskanymi z gmin, w których ten przekrój się znajduje

Table 3. The comparison of the number of days in a month and the low-water in the concrete water gauge cross-section with the information concerning the lack of water which was gained from the communes, in which we can find this cross-section

\begin{tabular}{|c|c|c|c|c|c|c|c|}
\hline \multirow{2}{*}{\multicolumn{4}{|c|}{$\begin{array}{c}\text { wodowskaz: Muszyna, rzeka: Poprad } \\
\text { gmina: Muszyna }\end{array}$}} & \multicolumn{4}{|c|}{ wodowskaz: Labowa, rzeka: Kamienica } \\
\hline & & & & \multicolumn{4}{|c|}{ gmina: Labowa } \\
\hline rok & miesiąc & $\begin{array}{l}\text { liczba } \\
\text { niżówek }\end{array}$ & $\begin{array}{c}\text { niedobory } \\
\text { wody } \\
\text { na obszarze } \\
\text { gmin }\end{array}$ & rok & miesiąc & $\begin{array}{l}\text { liczba niżó- } \\
\text { wek }\end{array}$ & $\begin{array}{c}\text { niedobory } \\
\text { wody } \\
\text { na obszarze } \\
\text { gmin }\end{array}$ \\
\hline \multirow{12}{*}{2012} & 1 & 31 & & \multirow{12}{*}{2013} & 1 & 30 & \\
\hline & 2 & 29 & tak & & 2 & & \\
\hline & 3 & 1 & & & 3 & & \\
\hline & 4 & & & & 4 & & \\
\hline & 5 & & & & 5 & & \\
\hline & 6 & & & & 6 & & \\
\hline & 7 & & & & 7 & 6 & \\
\hline & 8 & 22 & & & 8 & 31 & tak \\
\hline & 9 & 30 & tak & & 9 & 15 & \\
\hline & 10 & 31 & tak & & 10 & & \\
\hline & 11 & 30 & & & 11 & & \\
\hline & 12 & 31 & & & 12 & & \\
\hline \multirow{12}{*}{2013} & 1 & 31 & & & & & \\
\hline & 2 & 21 & tak & & & & \\
\hline & 3 & & tak & & & & \\
\hline & 4 & & & & & & \\
\hline & 5 & & & & & & \\
\hline & 6 & & & & & & \\
\hline & 7 & & & & & & \\
\hline & 8 & 29 & tak & & & & \\
\hline & 9 & 17 & tak & & & & \\
\hline & 10 & & & & & & \\
\hline & 11 & & & & & & \\
\hline & 12 & & & & & & \\
\hline
\end{tabular}


Tabela 3. Porównanie liczby dni z niżówką w danym miesiącu, w określonym przekroju wodowskazowym, z informacjami dotyczącymi braku wody pozyskanymi z gmin, w których ten przekrój się znajduje - c.d.

Table 3. The comparison of the number of days in a month and the low-water in the concrete water gauge cross-section with the information concerning the lack of water which was gained from the communes, in which we can find this cross-section - c.d.

\begin{tabular}{|c|c|c|c|c|c|c|c|}
\hline \multirow{2}{*}{\multicolumn{4}{|c|}{$\begin{array}{c}\text { wodowskaz: Muszyna-Milik, rzeka: Porad } \\
\text { gmina: Muszyna }\end{array}$}} & \multirow{2}{*}{\multicolumn{4}{|c|}{$\begin{array}{c}\text { wodowskaz: Stary Sącz, rzeka: Poprad } \\
\text { gmina: Stary Sącz }\end{array}$}} \\
\hline & & & & & & & \\
\hline rok & miesiąc & $\begin{array}{l}\text { liczba dni } \\
\text { niżówko- } \\
\text { wych }\end{array}$ & $\begin{array}{c}\text { dowóz } \\
\text { wody }\end{array}$ & rok & miesiąc & $\begin{array}{l}\text { liczba dni } \\
\text { niżówko- } \\
\text { wych }\end{array}$ & $\begin{array}{l}\text { dowóz } \\
\text { wody }\end{array}$ \\
\hline \multirow{12}{*}{2011} & 1 & & & \multirow{12}{*}{2011} & 1 & & \\
\hline & 2 & 4 & & & 2 & 5 & \\
\hline & 3 & 10 & & & 3 & 9 & \\
\hline & 4 & & & & 4 & & \\
\hline & 5 & & & & 5 & & \\
\hline & 6 & & & & 6 & & \\
\hline & 7 & & & & 7 & & tak \\
\hline & 8 & & & & 8 & & \\
\hline & 9 & 1 & & & 9 & 7 & \\
\hline & 10 & 22 & & & 10 & 21 & tak \\
\hline & 11 & 30 & tak & & 11 & 30 & tak \\
\hline & 12 & 31 & & & 12 & 31 & tak \\
\hline \multirow{12}{*}{2012} & 1 & 31 & & \multirow{12}{*}{2012} & 1 & 31 & tak \\
\hline & 2 & 28 & tak & & 2 & 28 & tak \\
\hline & 3 & & & & 3 & & tak \\
\hline & 4 & & & & 4 & & \\
\hline & 5 & & & & 5 & & \\
\hline & 6 & & & & 6 & & \\
\hline & 7 & & & & 7 & & \\
\hline & 8 & 14 & & & 8 & 15 & \\
\hline & 9 & 30 & tak & & 9 & 30 & tak \\
\hline & 10 & 31 & tak & & 10 & 31 & tak \\
\hline & 11 & 30 & & & 11 & 30 & tak \\
\hline & 12 & 31 & & & 12 & 31 & tak \\
\hline \multirow{12}{*}{2013} & 1 & 31 & & \multirow{12}{*}{2013} & 1 & 31 & tak \\
\hline & 2 & 21 & tak & & 2 & 14 & tak \\
\hline & 3 & & tak & & 3 & & tak \\
\hline & 4 & & & & 4 & & \\
\hline & 5 & & & & 5 & & \\
\hline & 6 & & & & 6 & & \\
\hline & 7 & & & & 7 & & \\
\hline & 8 & 18 & tak & & 8 & 20 & tak \\
\hline & 9 & 16 & tak & & 9 & 16 & tak \\
\hline & 10 & & & & 10 & & tak \\
\hline & 11 & & & & 11 & & \\
\hline & 12 & & & & 12 & & \\
\hline
\end{tabular}


Tabela 3. Porównanie liczby dni z niżówką w danym miesiącu, w określonym przekroju wodowskazowym, z informacjami dotyczącymi braku wody pozyskanymi z gmin, w których ten przekrój się znajduje - c.d.

Table 3. The comparison of the number of days in a month and the low-water in the concrete water gauge cross-section with the information concerning the lack of water which was gained from the communes, in which we can find this cross-section - c.d.

\begin{tabular}{|c|c|c|c|c|c|c|c|}
\hline \multirow{2}{*}{\multicolumn{4}{|c|}{$\begin{array}{c}\text { wodowskaz: Jagodniki, rzeka: Wisła } \\
\text { gmina: Opatowiec }\end{array}$}} & \multirow{2}{*}{\multicolumn{4}{|c|}{$\begin{array}{c}\text { wodowskaz: Jakubkowice, rzeka: Lososina } \\
\text { gmina: Lososina Dolna }\end{array}$}} \\
\hline & & & & & & & \\
\hline rok & miesiąc & $\begin{array}{c}\text { liczba dni } \\
\text { niżówko- } \\
\text { wych }\end{array}$ & dowóz wody & rok & miesiąc & $\begin{array}{c}\text { liczba dni } \\
\text { niżówko- } \\
\text { wych }\end{array}$ & dowóz wody \\
\hline \multirow{12}{*}{2007} & 1 & 2 & & \multirow{12}{*}{2011} & 1 & & \\
\hline & 2 & & & & 2 & & \\
\hline & 3 & & & & 3 & & \\
\hline & 4 & 4 & & & 4 & & \\
\hline & 5 & 31 & & & 5 & & \\
\hline & 6 & 15 & tak & & 6 & & \\
\hline & 7 & 26 & tak & & 7 & & \\
\hline & 8 & 31 & tak & & 8 & & \\
\hline & 9 & 5 & tak & & 9 & 30 & \\
\hline & 10 & & tak & & 10 & 31 & \\
\hline & 11 & & & & 11 & 30 & \\
\hline & 12 & & & & 12 & 31 & tak \\
\hline \multirow{12}{*}{2008} & 1 & & & \multirow{12}{*}{2012} & 1 & 31 & tak \\
\hline & 2 & & & & 2 & 23 & tak \\
\hline & 3 & & & & 3 & & tak \\
\hline & 4 & & & & 4 & & \\
\hline & 5 & 11 & & & 5 & 5 & \\
\hline & 6 & 30 & tak & & 6 & 5 & \\
\hline & 7 & 13 & tak & & 7 & 31 & \\
\hline & 8 & 13 & tak & & 8 & 31 & \\
\hline & 9 & 16 & tak & & 9 & 30 & tak \\
\hline & 10 & & tak & & 10 & 31 & tak \\
\hline & 11 & 15 & & & 11 & 30 & tak \\
\hline & 12 & & & & 12 & 17 & tak \\
\hline \multirow{12}{*}{2009} & 1 & & & \multirow{12}{*}{2013} & 1 & & tak \\
\hline & 2 & & & & 2 & & tak \\
\hline & 3 & & & & 3 & & tak \\
\hline & 4 & & & & 4 & & tak \\
\hline & 5 & & & & 5 & & \\
\hline & 6 & 15 & tak & & 6 & & \\
\hline & 7 & 0 & tak & & 7 & & \\
\hline & 8 & 19 & tak & & 8 & & tak \\
\hline & 9 & 30 & tak & & 9 & & \\
\hline & 10 & 11 & & & 10 & & \\
\hline & 11 & & & & 11 & & \\
\hline & 12 & & & & 12 & & \\
\hline
\end{tabular}


Tabela 3. Porównanie liczby dni z niżówką w danym miesiącu, w określonym przekroju wodowskazowym, z informacjami dotyczącymi braku wody pozyskanymi z gmin, w których ten przekrój się znajduje - c.d.

Table 3. The comparison of the number of days in a month and the low-water in the concrete water gauge cross-section with the information concerning the lack of water which was gained from the communes, in which we can find this cross-section - c.d.

\begin{tabular}{|c|c|c|c|c|c|c|c|}
\hline \multirow{2}{*}{\multicolumn{4}{|c|}{$\begin{array}{c}\text { wodowskaz: Gołkowice rzeka: Dunajec } \\
\text { gmina: Podegrodzie }\end{array}$}} & \multicolumn{4}{|c|}{ wodowskaz: Karsy rzeka: Wisła } \\
\hline & & & & \multicolumn{4}{|c|}{ gmina: Opatowiec } \\
\hline rok & miesiąc & $\begin{array}{l}\text { liczba dni } \\
\text { niżówko- } \\
\text { wych }\end{array}$ & dowóz wody & rok & miesiąc & $\begin{array}{l}\text { liczba dni } \\
\text { niżówko- } \\
\text { wych }\end{array}$ & dowóz wody \\
\hline \multirow{12}{*}{2011} & 1 & & & \multirow{12}{*}{2007} & 1 & 3 & \\
\hline & 2 & & & & 2 & & \\
\hline & 3 & & & & 3 & & \\
\hline & 4 & & & & 4 & & \\
\hline & 5 & & & & 5 & & \\
\hline & 6 & & & & 6 & 1 & tak \\
\hline & 7 & & & & 7 & 26 & tak \\
\hline & 8 & & & & 8 & 13 & tak \\
\hline & 9 & 14 & & & 9 & & tak \\
\hline & 10 & 31 & & & 10 & & tak \\
\hline & 11 & 30 & tak & & 11 & & \\
\hline & 12 & 31 & tak & & 12 & & \\
\hline \multirow{12}{*}{2012} & 1 & 31 & tak & \multirow{12}{*}{2008} & 1 & & \\
\hline & 2 & 10 & tak & & 2 & & \\
\hline & 3 & & & & 3 & & \\
\hline & 4 & & & & 4 & & \\
\hline & 5 & & & & 5 & & \\
\hline & 6 & & & & 6 & 11 & tak \\
\hline & 7 & & & & 7 & 5 & tak \\
\hline & 8 & 24 & & & 8 & 10 & tak \\
\hline & 9 & 30 & tak & & 9 & 17 & tak \\
\hline & 10 & 31 & tak & & 10 & 0 & tak \\
\hline & 11 & 4 & tak & & 11 & 14 & \\
\hline & 12 & & tak & & 12 & & \\
\hline \multirow{12}{*}{2013} & 1 & 30 & tak & & & & \\
\hline & 2 & 24 & tak & & & & \\
\hline & 3 & & & & & & \\
\hline & 4 & & tak & & & & \\
\hline & 5 & & & & & & \\
\hline & 6 & & & & & & \\
\hline & 7 & & & & & & \\
\hline & 8 & & & & & & \\
\hline & 9 & & & & & & \\
\hline & 10 & & & & & & \\
\hline & 11 & & & & & & \\
\hline & 12 & & & & & & \\
\hline
\end{tabular}




\section{Literatura}

[1] Beran M. A. Rodier J. A.: Hydrological aspects of drought. Unesco- WMO, Geneva, 1985, s. 39-151.

[2] Drab E. Bukowiec T. Mączka M.: Zjawisko suszy na obszarze działania RZGW w Krakowie w 2003 r. RZGW w Krakowie, 2004.

[3] Drab E.: Zjawisko suszy na obszarze działania RZGW w Krakowie w latach: 2003 i 2011, RZGW Kraków 2012, s. 36.

[4] Fleig A. K.: Hydrological Drought - A comparative study using daily discharge series from around the world. MSc thesis, Albert-Ludwigs-Universität Freiburg, Freiburg, Germany, 2004, s. 170.

[5] Hisdal H., Tallaksen L. M.: Drought Event Definition. Technical Report No. 6. Assessment of the Regional Impact of Droughts in Europe, Department of Geophysics, University of Oslo, 2000, s. 45.

[6] Jakubowski W.: Rozkłady prawdopodobieństwa w ocenie suszy hydrologicznej. Monografia, Uniwersytet Przyrodniczy, Wrocław, 2011, s. 177.

[7] Kostuch M.: Charakterystyka niżówek w potokach górskich w zlewniach o różnej lesistości. Woda-Środowisko-Obszary Wiejskie, Instytut Melioracji i Użytków Zielonych, Raszyn, 2004, s. 63-71.

[8] Lorenc H. Ceran M. Mierkiewicz M. Sasim M. Wita A.: 2006 Susza w Polsce - 2006 rok (przyczyny. natężenie. zasięg. wnioski na przyszość). Raport IMGW, 2006.

[9] Łabędzki L. :Problematyka susz w Polsce. Woda Środowisko Obszary Wiejskie. T. 4 z. 1., 2004, s. 47-66.

[10] Magnuszewski A. Soczyńska U. (red.) Międzynarodowy Słownik Hydrologiczny. Wydawnictwo Naukowe PWN. Warszawa, 2001.

[11] National Disaster Management Centre. Drought awareness. South African Weather Service National Drought Mitigation Center. http://drought.unl.edu/.

[12] Ozga-Zielińska M., Brzeziński J.: Hydrologia stosowana. Wydawnictwo Naukowe PWN, wydanie 2 zmienione, Warszawa, 1997, s. 324.

[13] Parry S. Hannaford J. Lloyd-Hughes B. Prudhomme C.: Multi-year droughts in Europe: analysis of development and causes. Centre for Ecology and Hydrology. Hydrology Research. 43.5, 2012.

[14] Pociask-Karteczka J. red.: Zlewnia. Właściwości i proces. Instytut Geografii i Gospodarki Przestrzennej Uniwersytetu Jagiellońskiego, Kraków 2003, 288 s.

[15] Ratomska B.: Ocena suszy w aspekcie hydrologicznym. Praca doktorska, Politechnika Krakowska, 1993, s. 131.

[16] Rozporządzenie Ministra Rolnictwa i Rozwoju Wsi z dnia 9 maja 2007 r. w sprawie wartości klimatycznego bilansu wodnego dla poszczególnych gatunków roślin uprawnych i gleb. Dz. U. 2007 nr 90 poz. 601.

[17] Smakhtin V. U.: Low flow hydrology: a review. Journal of Hydrology 240, 2001, s. 147-186.

[18] Stahl K.: Hydrological Drought - a study across Europe. PhD Thesis AlbertLudwigs Universitaet Freiburg, Freiburger Schriften zur Hydrologie no 15, Freiburg, Germany, 2001, s. 144. 
[19] Tallaksen L. M., Van Lanen H. A. J.: Key aspects of low flow and drought. Würzburg workshop on "Low flow and Droughts", 2004, s. 63.

[20] Tokarczyk T.: Classification of Low Flow and Hydrological Drought for a River Basin. Acta Geophysica, Vol. 61, No. 2, 2013, s. 404-421.

[21] Tomaszewski E.: Wieloletnia i sezonowa dynamika niżówek w rzekach środkowej Polski. Wydawnictwo Uniwersytetu Łódzkiego, Łódź, 2012, s. 262.

[22] Van Lanen H. A. J., Kundzewicz Z., Tallaksen L. M., Hisdal H., Fendeková M., Prudhomme C.: Indices for different types of droughts and floods at different scales. Technical Report No. 11, WATCH Water and Global Change, 2008, s. 20.

[23] Van Loon A., Van Lanen H. A. J., Tallaksen L. M., Hanel M., Fendeková M., Machlica A., Sapriza G., Koutroulis A., Van Huijgevoort M., Bermúdez J.J., Hisdal H., Tsanis I.: Propagation of drought through the hydrological cycle. Technical Report No. 31, WATCH Water and Global Change, 2011, s. 99.

[24] Węglarczyk S. red.: Słownik terminów związanych z gospodarowaniem zasobami wodnymi. Wydawnictwo Politechniki Krakowskiej, 2006, s. 94.

[25] Wilhite D. A. Glantz M. H.: Understanding the drought phenomenon: the role of definitions. [w:] Wilhite D. A. Easterling W. E. Wood D. A. (eds.). Planning for Drought: Toward a Reduction of Societal Vulnerability. Western Press, Boulder. CO, 1987, s. 11-30.

[26] Zelenhasic E., Salvai A.: A Method of Streamflow Drought Analysis. Water Resources Research Vol. 23, No. 1, 1987, s. 156-168.

\title{
THE SOCIAL-ECONOMIC DROUGHT AND THE HYDROLOGICAL DROUGHT IN THE UPPER VISTULA RIVER BASIN
}

\begin{abstract}
S u m m a r y
The main aim of this paper is to compare the periods of deficit of river water (hydrological drought) with the periods of the deficit of water used for the living and communal-economic purposes (social-economic drought), which were noticed in the communes in the upper Vistula river basin, between 1984-2014. The observed co-existence of these periods can make easier the prevision of the risk of drought and the better preparation for it (particularly in the offices and the institutions engaged in the water distribution or the natural disasters).

The low-water, identified with the hydrological drought, was set with the SPA method, assuming the border flow of $\mathrm{Q}_{70 \%}$ and the minimal duration of 7 days.

The periods with deficit of water was set on the information gained from the questionnaires which were sent to the district and communal authorities and the other institutions engaged in water supplies.
\end{abstract}

Keywords: low flow, drought deficit, drought duration, the questionnaire in municipalities, hydrological drought, socio-economic drought

Przestano do redakcji: 30.05 .2015 r.

Przyjęto do druku: 30.10.2015 r.

DOI: $10.7862 / r b .2015 .92$ 